\title{
PENDEKATAN METAKOGNITIF DALAM PEMBELAJARAN MATEMATIKA UNTUK PENCAPAIAN KEMAMPUAN KONEKSI DAN PEMECAHAN MASALAH MATEMATIK SISWA SMA
}

\author{
Desy Ayu Nurasyiyah \\ Universitas Pendidikan Indonesia \\ desyayunurasyiah@gmail.com
}

\begin{abstract}
Background of the investigation is the process involves the full awareness of the learning process is still lacking. As a result, the level of attainment of students' mathematical ability is still not meet the minimum level of mastery learning expected. Among the abilities are still lacking is the ability to connect and solving mathematical problems. This study implements mathematical learning with metacognitive approach and want to see its effect on the attainment of connection capability and mathematical problem solving. The purpose of this study was to see impact of learning mathematics with metacognitive approach to the attainments of students in connection and mathematical problem solving ability. as well as how the students' response to this study. The method used is the method Quasi-experimental when the design is the only post respons control group. Participants of this study were students of class X in High School, is located in Bandung district. Instruments used in the research is a matter of post test connection and problem solving ability, then used also student attitude scale, students daily journal, observation and interview guides. Based on the results we concluded that there was no significant difference to the attainment of the connection and mathematical problem solving ability. Being from the results of the questionnaire, the students daily journal, observation and interviews showed a positive response to the learning of mathematics with metacognitive approach
\end{abstract}

Keywords: metacognitive, connections, and mathematical problems solving

\begin{abstract}
ABSTRAK. Penelitian ini dilatarbelakangi karena kurang pembelajaran yang melibatkan kesadaran berfikir. Sehingga pembelajaran yang berlangsung menjadi kurang bermakna. Hal ini menyebabkan pencapaian kemampuan matematis siswa belum memenuhi tingkat ketuntasan belajar minimal yang diharapkan. Diantara kemampuan-kemampuan yang masih kurang itu adalah kemampuan koneksi dan pemecahan masalah matematik. Penelitian ini mengimplementasikan pembelajaran matematika dengan pendekatan metakognitif dan ingin melihat pengaruhnya terhadap pencapaian kemampuan koneksi dan pemecahan masalah matematik. Tujuan dari penelitian ini adalah untuk mengetahui pencapaian yang diperoleh siswa dalam kemampuan koneksi dan pemecahan masalah matematik setelah dilakukannya pembelajaran dengan pendekatan metakognitif, serta bagaimana respon siswa terhadap pembelajaran ini. Metode penelitian yang digunakan adalah metode kuasi eksperimen dengan desain post respon dengan kelas control. Partisipan dari penelitian ini adalah siswa kelas X SMA yang terletak di daerah Kab. Bandung. Instrumen yang digunakan dalam penelitian berupa soal post tes kemampuan koneksi dan pemecahan masalah, kemudian digunakan juga angket siswa, jurnal harian siswa, lembar observasi dan pedoman wawancara. Berdasarkan hasil penelitian diperoleh
\end{abstract}


kesimpulan bahwa tidak ada perbedaan yang cukup berarti terhadap pencapaian kemampuan koneksi dan pemecahan masalah matematik. Sedang dari hasil angket, jurnal harian siswa, lembar observasi dan wawancara menunjukkan respon positif terhadap pembelajaran matematika dengan pendekatan metakognitif.

Kata kunci : metakognitif, koneksi dan pemecahan masalah matematik.

\section{PENDAHULUAN}

Kemampuan-kemampuan yang dikembangkan dalam pembelajaran matematika adalah pemahaman, penalaran, koneksi, investigasi, komunikasi, observasi, eksplorasi, inkuiri, konjektur, hipotesis, generalisasi, kreativitas, dan pemecahan masalah (Suherman, 2008). Pada kenyataannya, pencapaian kemampuan-kemampuan tersebut masih rendah. Salah satu penyebabnya adalah waktu yang tersedia untuk proses pembelajaran lebih sedikit dibanding beban yang harus diajarkan, sehingga proses pembelajaran yang dipilih bersifat mekanistik.

Untuk kemampuan koneksi, dari hasil penelitian Ruspiani (2000) dilaporkan bahwa kemampuan koneksi matematika siswa SMA masih rendah. Kemudian menurut hasil penelitian yang dilakukan oleh Trends In Mathematic and Science Study (TIMMS) 2003 siswa Indonesia hanya berada di ranking ke-35 dari 44 negara dalam hal prestasi matematika dan di ranking ke-37 dari 44 negara dalam hal prestasi sains. Mullis (Herman dan Suryadi, 2008) mengungkapkan bahwa soal yang dikembangkan pada studi TIMMS mencakup empat ranah kognitif yakni pengetahuan tentang fakta dan prosedur, penggunaan konsep, pemecahan masalah rutin dan penalaran matematik. Ini menunjukan bahwa kemampuan pemecahan masalah dan koneksi matematika siswa Indonesia masih rendah.

Penyebab kurang optimalnya pencapaian kemampuan koneksi dan pemecahan masalah matematik adalah masih kurangnya proses melibatkan kesadaran siswa dalam belajar. Akibatnya kemampuan yang dicapai berupa kemampuan rendah yakni berupa algoritma rutin dan hafalan. Proses belajar yang dilakukan hanya membentuk siswa yang bisa melakukan prosedur matematik 
tertentu tanpa mengetahui alasan yang mendasarinya. Akhirnya ketika menemui permasalahan yang tidak biasa siswa cenderung untuk menyerah dan menganggap hal itu di luar kemampuannya.

Kesadaran dalam proses belajar sangatlah penting. Fontana (Suherman, 2001) mengatakan bahwa belajar adalah perubahan tingkah laku yang cenderung menetap dan dilakukan secara sadar. Ini berarti bahwa kesadaran adalah komponen penting yang harus dilibatkan dalam proses pembelajaran secara keseluruhan. Melihat pentingnya melibatkan proses kesadaran dalam belajar, maka perlu bagi kita untuk menggunakan pembelajaran matematika yang melibatkan proses kesadaran siswa. Salah satu alternatif pembelajaran yang melibatkan cara berfikir siswa secara sadar adalah pembelajaran dengan pendekatan metakognitif.

Pembelajaran dengan pendekatan metakognitif menurut Kramarski dan Zoldan (2008) adalah pembelajaran yang menanamkan kesadaran bagaimana merancang, memonitor, serta mengontrol tentang apa yang mereka ketahui; apa yang diperlukan untuk mengerjakan; menitikberatkan pada aktivitas belajar; membantu dan membimbing siswa ketika mengalami kesulitan; serta membantu siswa dalam mengembangkan konsep diri mereka ketika sedang belajar matematika.

Pembelajaran metakognitif mengajak siswa untuk mengembangkan konsep belajarnya. Siswa bisa menyadari pentingnya penguasaan sebuah kemampuan matematika, melatih kemandirian untuk belajar, dan memungkinkan siswa untuk menyadari kekurangan dan kelebihannya, sehingga dapat melakukan kontrol terhadap pengetahuannya. Oleh karena itu, berdasarkan paparan di atas peneliti bermaksud untuk meneliti tentang pengaruh penggunaan pendekatan Metakognitif dalam pembelajaran Matematika terhadap pencapaian kemampuan koneksi dan pemecahan masalah matematis.

Berdasarkan uraian di atas, maka penilitian ini memiliki rumusan masalah sebagai berikut : 
1. Apakah pencapaian kemampuan koneksi matematik siswa di kelas yang pembelajarannya menggunakan pendekatan metakognitif lebih baik daripada siswa di kelas yang pembelajarannya secara konvensional?

2. Apakah pencapaian kemampuan pemecahan masalah matematik siswa di kelas yang pembelajarannya menggunakan pendekatan metakognitif lebih baik daripada siswa di kelas yang pembelajarannya secara konvensional?

3. Bagaimana respon siswa terhadap pembelajaran matematika dengan menggunakan pendekatan metakognitif?

Sedangkan untuk manfaat dan kontribusi yang diharapkan dari penelitian ini adalah untuk menambah referensi pembelajaran inovatif dalam meningkatakan kemampuan koneksi dan pemecahan masalah matematik siswa. Selain itu, penelitian ini diharapkan akan menjadi solusi dari masalah berupa sedikitnya waktu yang dimiliki guru dalam mengajar.

\section{METODE PENELITIAN}

Pada penelitian ini dilakukan implementasi pembelajaran matematika dengan pendekatan metakognitif dan ingin dilihat dampaknya terhadap pencapaian kemampuan koneksi dan pemecahan masalah matematik. Oleh karena itu, metode dari penelitian ini berbentuk penelitian Kuasi eksperimen. Sedangkan disain penelitian yang digunakan pada penelitian ini adalah disain kelompok kontrol hanya post-respons.(Russeffendi, 1998).

Partisipan dalam penelitian ini adalah siswa kelas $\mathrm{X}$, jumlah kelas $\mathrm{X}$ di salah satu SMA negeri di Kab. Bandung sebanyak 8 kelas. Pada tiap kelas yang ada sebaran dari kemampuan tiap siswa memiliki karakteristik yang sama. Penyebaran siswa yang memiliki kemampuan tinggi, sedang, dan rendah relatif sama pada tiap kelas. Dalam penelitian ini diambil 2 kelas $(\mathrm{n}=76)$ untuk dijadikan kelas eksperimen dan kelas kontrol. Adapun instrumen yang digunakan dalam penelitian ini terdiri dari tes kemampuan koneksi dan pemecahan masalah matematik; angket; jurnal siswa dan pedoman wawancara. 


\section{HASIL DAN PEMBAHASAN}

\subsection{Hasil Penelitian}

Data hasil penelitian diperoleh dari tes kemampuan koneksi dan pemecahan masalah matemati serta angket. Sedangkan hasil wawancara dan jurnal siswa digunakan untuk melengkapi hasil dari kedua data di atas.

Tabel 1

Data hasil tes kemampuan koneksi dan pemecahan masalah matematik

\begin{tabular}{|l|l|l|l|l|}
\hline & \multicolumn{2}{|c|}{ Koneksi Matematik } & \multicolumn{2}{c|}{$\begin{array}{c}\text { Pemecahan Masalah } \\
\text { Matematik }\end{array}$} \\
\hline & Metakognitif & Konvensional & Metakognitif & Konvensional \\
\hline Skor terendah & 11 & 11 & 0 & 0 \\
\hline Skor tertinggi & 78 & 78 & 38 & 50 \\
\hline Rata-rata skor & 32,2 & 38.3 & 21,4 & 24,22 \\
\hline $\begin{array}{l}\text { Jumlah siswa yang } \\
\text { mencapai KKM }\end{array}$ & 13 & 16 & - & 2 \\
\hline Jumlah siswa & 37 & 39 & 37 & 39 \\
\hline SMI & 100 & 100 & 100 & 100 \\
\hline
\end{tabular}

\subsection{Pembahasan}

Proporsi diperoleh dari banyaknya siswa yang mencapai kriteria ketuntasan minimal kompetensi dasar (KKM KD) yang disesuaikan dengan keadaan sekolah masing-masing. KKM KD yang ditetapkan pada penelitian ini adalah sekitar $44 \%$. Hal ini ditentukan berdasarkan pedoman penyusunan KKM khusus SMA. Dalam penyususnan KKM ini sangat diperhatikan tiga buah komponen yaitu daya dukung, tingkat kompleksitas dan intake siswa.

Berdasarkan analisis tentang kondisi partisipan terhadap ketiga komponen di atas, maka peneliti mengambil batas KKM KD sebesar $44 \%$. Ini terjadi karena tingkat kompleksitas untuk KD yang ada pada bahan ajar cukup tinggi. Serta kemampuan yang ingin dicapai pun merupakan kemampuan tingkat tinggi. Sementara untuk daya dukung dapat dikategorikan sedang dan intake siswa dapat dikategorikan rendah. 
Banyaknya siswa yang mencapai skor lebih dari atau sama dengan KKM KD pada tes kemampuan koneksi matematika di kelas yang memperoleh pembelajaran dengan pendekatan metakognitif sebanyak 13 orang. Sedangkan di kelas yang pembelajarannya secara konvensional banyaknya siswa yang mencapai skor lebih dari atau sama dengan KKM KD untuk tes kemapuan koneksi matematika adalah 16 orang. Meskipun secara kasar terlihat bahwa hasil yang dicapai siswa yang pembelajarannya secara konvensional lebih baik, namun hal ini belum bisa diambil kesimpulan bahwa pencapaian KKM di kelas kontrol lebih baik, karena masih perlu dilakukan pengujian hipotesis terlebih dahulu.

Uji hipotesis yang dilakukan adalah dengan menggunakan uji proporsi. Dari hasil uji proporsi diperoleh kesimpulan bahwa tidak ada perbedaan yang cukup berarti. Ini berarti bahwa tidak ada perbedaan yang cukup signifikan antara siswa yang mendapatkan pembelajaran dengan pendekatan metakognitif dan siswa yang pembelajarannya secara konvensional terhadap tingkat pencapaian kemampuan koneksi matematika.

Dalam mencapai kemampuan koneksi menurut Coxford dan House (1995) terdapat tiga aspek yang berelasi pada konsep koneksi matematika, yaitu (1) penyatuan tema-tema, (2) proses matematika, (3) konektor matematika. Dalam aspek penyatuan tema-tema, siswa melakukan identifikasi terhadap informasiinformasi yang ada, baik itu berupa data, pola atau bentuk sehingga siswa dapat mengambil ide utamanya. Siswa yang berhasil melakukan tahapan-tahapan tersebut akan memiliki kemampuan koneksi yang baik. Sedangkan siswa yang tidak dapat melakukan tahapan-tahapan tersebut akan sulit dalam mencapai kemampuan koneksi. Hal inilah yang dialami oleh hampir semua siswa dalam penelitian ini.

Pentingnya kemampuan mengidentifikasi masalah diungkapkan juga oleh Butler dan Wren (Ruspiani, 2000) bahwa siswa harus membaca dan menganalisa soal untuk bisa membuat model, grafik, atau representasi matematika yang lain. Akan tetapi menurutnya aktivitas ini juga yang banyak menimbulkan kesulitan bagi siswa. Hal yang sama pun terjadi pada penelitian ini, siswa kebanyakan 
merasa kesulitan untuk mengungkapkan ide awal yang harus mereka temukan. Hal ini pun didukung oleh hasil jurnal siswa dan analisis lembar observasi.

Dalam penelitian ini, kemampuan koneksi yang diukur bukan hanya koneksi antar topik matematika saja. Tetapi juga koneksi terhadap disiplin ilmu lainnya dan koneksi terhadap kehidupan sehari-hari. Dari tes yang dilakukan kebanyakan siswa baik untuk kemampuan koneksi antar topik matematika. Sedangkan untuk koneksi terhadap disiplin ilmu lainnya dan koneksi pada kehidupan sehari-hari hanya sedikit yang bisa hanya $13,5 \%$ siswa dari keseluruhan. Hal ini kemungkinan karena siswa kesulitan untuk membuat model yang tepat dan lupa dengan rumus pada disiplin ilmu lainnya.

Siswa tidak cukup mengerti dan paham dengan hasil identifikasinya. Siswa sulit untuk menerjemahkan permasalahan yang diberikan, sehingga jawaban yang diberikan tidak sesuai dengan tema pembelajaran atau materi. Padahal menurut Fisher (Ruspiani, 2000) menciptakan pengertian sangatlah penting dalam koneksi matematika, sebab melakukan koneksi berarti cara untuk menciptakan pengertian.

Sedangkan untuk tingkat pencapaian kemampuan pemecahan masalah matematik, terjadi hal yang sama seperti pada kemampuan koneksi matematik. Dari hasil pengujian hipotesis diperoleh kesimpulan bahwa tidak terjadi perbedaan yang cukup berarti. Perbedaan yang terjadi, tidak cukup signifikan untuk menyimpulkan mana yang lebih baik tingkat pencapaiannya antara siswa yang pembelajarannya dengan pendekatan metakognitif dan siswa yang pembelajarannya secara konvensional.

Ketidaktercapaian kemampuan pemecahan masalah matematik tidak terlalu mengherankan, karena menurut Hodgson (Coxford dan House, 1995) koneksi matematika adalah sebagai alat dari pemecahan masalah atau 'connection as problem - solving tools', berarti hal ini menunjukan hasil yang dicapai untuk kemampuan pemecahan masalah dipengaruhi oleh kemampuan koneksi. Pencapaian pada siswa di kelas yang pembelajarannya menggunakan pendekatan metakognitif hanya sekitar 35\% untuk kemampuan koneksi, sedang untuk kemampuan pemecahan masalah adalah $41 \%$ untuk siswa di kelas yang 
pembelajarannya secara konvensional. Hal ini berakibat pada rendahnya hasil yang dicapai untuk kemampuan pemecahan masalah.

Pada penelitian ini siswa dari awal sulit untuk bisa memahami soal, terlebih sampai pada tahap pembuatan model. Siswa dari tahap awal penyelesaian soal sudah sulit untuk bisa memahami soal. Siswa menyatakan kesulitan dengan soal yang diberikan, sebab soal tersebut tidak seperti yang biasa mereka dapatkan. Hal ini banyak diungkapkan siswa pada jurnal yang telah diberikan serta dari hasil observasi yang dilakukan, siswa terlihat kurang memahami soal, akibat dari tidak biasanya mereka mendapatkan soal tipe pemecahan masalah. Hal ini sejalan dengan Davis (Ruspiani, 2000) bahwa Tahapan memahami soal merupakan hal yang sulit dalam proses belajar mengajar. Akibatnya, siswa pun tidak bisa atau kesulitan untuk sampai pada tahap selanjutnya dalam menyelesaikan soal.

Hasil yang dicapai oleh siswa di kelas dengan pembelajaran metakognitif tidaklah lebih baik dari siswa di kelas yang pembelajarannya secara konvensional. Padahal seharusnya siswa tersebut memiliki kemampuan yang lebih baik, karena menurut Nugrahaningsih (2008) metakognisi memiliki peranan penting dalam proses pemecahan masalah. Ini berarti bahwa pembelajaran dengan pendekatan metakognitif harusnya dapat membawa siswa kepada pencapaian kemampuan pemecahan masalah yang lebih baik.

Dengan kesadaran yang ingin dibangun dalam pembelajaran metakognitif ini, siswa diajak untuk mendalami dirinya sendiri sehingga mengetahui apa yang diketahui dan yang tidak diketahuinya. Akibatnya siswa akan melakukan balikan dengan mencari apa yang ingin diketahuinya dengan bertanya pada diri sendiri, teman atau guru. Dari hasil angket diketahui bahwa siswa merasakan pertanyaanpertanyaan dalam dirinya. Pertanyaan-pertanyaan ini yang seharusnya membawa siswa pada jawaban, akan tetapi karena belum terbiasa beradaptasi hal ini malah berakibat membawanya pada situasi yang sulit. Ini terlihat juga dari hasil angket, jurnal, dan wawancara dengan siswa.

Sementara itu untuk hasil wawancara dengan guru dan siswa diperoleh data bahwa guru memiliki respons yang baik. Hal ini akan menambah wawasan siswa dan melatih siswa untuk belajar mandiri. Namun guru memberikan 
pendapat dengan keadaan siswa yang masih kurang. Pembelajaran seperti ini akan menyita waktu yang banyak dan agar lebih efisien hendaknya terlebih dahulu dilakukan pemaparan materi dan pemberian contoh soal. Hal senada pun diungkapkan oleh sebagian siswa baik dari hasil wawancara angket, maupun jurnal. Siswa sangat sulit untuk meninggalkan kebiasaan belajar sebelumnya. Siswa merasa bahwa penyampaian secara detil dan dijelaskan secara langsung sangatlah memudahkan mereka. Begitupun yang diungkapkan oleh guru kelas, dengan kemampuan siswa yang rata-rata kurang, maka cara mengajar yang paling efisien adalah dengan mengajar secara langsung. Akan tetapi hal inilah yang membuat kemampuannya tidak berkembang. Seperti dituturkan oleh Peterson dan Fennema (Herman dan Suryadi, 2008) bahwa cocok untuk meningkatkan kemampuan berfikir rendah. Meskipun menurut Ausubel (Suherman, 1994) dalam teori belajar bermaknanya. Kebermaknaan dalam belajar tidak terpatok pada satu model atau cara pengajaran saja yang cocok tapi lebih kepada kecocokkan terhadap karakteristik siswa.

\section{KESIMPULAN DAN SARAN}

Berdasarkan hasil penelitian yang telah dilakukan dan pembahasan di atas, dapat disimpulkan bahwa:

a. Tidak ada perbedaan yang signifikan untuk pencapaian kemampuan koneksi matematik antara siswa yang pembelajarannnya menggunakan pendekatan metakognitif dengan siswa yang pembelajarannya secara konvensional.

b. Tidak ada perbedaan yang signifikan untuk pencapaian kemampuan pemecahan masalah matematik antara siswa yang pembelajarannnya menggunakan pendekatan metakognitif dengan siswa yang pembelajarannya secara konvensional.

c. Respons siswa terhadap pembelajaran matematika dengan pendekatan metakognitif positif. Hal ini terlihat dari hasil angket, jurnal dan wawancara. Siswa merasa wawasannya lebih bertambah dan mendapatkan 
suasana baru. Terlebih siswa dalam pembelajaran ini dilatih untuk belajar secara mandiri.

Adapun saran dalam penelitian ini yang didasarkan pada hasil penelitian dan kesimpulan adalah sebagai berikut :

a. Dari penelitian ini diperoleh hasil bahwa tidak ada perbedaan yang cukup berarti terhadap pencapaian kemampuan koneksi dan pemecahan masalah matematika. Mungkin diakibatkan kurang lamanya waktu penelitian, yang berakibat pada masih kurang optimalnya kesadaran siswa yang terbangun. Oleh karena itu hendaknya penelitian dilakukan dalam rentang waktu yang cukup lama misalnya sampai selesai satu standar kompetensi.

b. Hendaknya terlebih dahulu dilakukan pengerjaan soal secara mandiri untuk soal yang akan didiskusikan. Hal ini agar ketika diskusi kelompok masing-masing siswa sudah siap dengan argumennnya, sehingga diskusi lebih efektif.

c. Penelitian ini merupakan penelitian eksperimen. Dalam penelitian ini sangat diperhatikan sekali kondisi belajar individual siswa. Disarankan agar dilakukan juga penelitian tindakan kelas sehingga dapat membantu untuk mengatasi masalah dalam lingkup yang lebih kecil lagi.

d. Dalam penelitian ini, aspek pembelajaran metakognitif yang masih kurang adalah regulasi. Hendaknya soal yang diberikan memberi kesempatan kepada siswa untuk bisa melakukan proses regulasi.

e. Hendaknya setiap guru matematika membiasakan agar siswa mengerjakan soal seperti tahapan penyelesaian soal menurut Polya. Hal ini dimaksudkan agar siswa menyadari setiap proses dalam pengerjaan soal.

f. Hendaknya guru memberikan pemaknaan pada saat menerangkan kepada siswa. Hal ini dimaksudkan agar siswa sadar dengan apa yang diterangkan oleh guru. 


\section{UCAPAN TERIMAKSIH}

Penyusun mengucapkan terima kasih yang sebesar-besarnya terhadap beberapa pihak yang telah membantu dalam pelaksanaan penelitian ini, terutama kepada Bapak Dr. Dadang Juandi M.Si dan Dr. Jarnawi A.Dahlan M.Kes. yang telah memberikan saran dan bimbingannya.

\section{DAFTAR PUSTAKA}

Coxford, A. F and House, P. A. (1995). Connecting Mathematics accross the Curriculum, The National Council of Teachers of Mathematics, Virginia.

Herman, T dan Suryadi, D. (2008). (Eksplorasi Matematika) Pembelajaran Pemecahan Masalah, Karya Duta Wahana, Jakarta.

Kramarski, B dan Zoldan, S. (2008). Using errors as spingboard for enhancing Mathematical Reasoning With Three Metacognitive Approaches. Proquest Journal.

Nugrahaningsih, T. K. (2008). "Peran Metakognisi dalam Menyelesaikan Masalah Matematika". Makalah pada Seminar Nasional MatematikaFKMS3MI Surabaya.

Ruseffendi, E.T. (1998). Dasar-Dasar Penelitian Pendidikan dan Bidang NonEksakta Lainnya, IKIP Semarang Press, Semarang.

Ruspiani. (2000). Kemampuan Siswa dalam Melakukan Koneksi Matematika. Tesis pada PPS UPI: Tidak diterbitkan.

Suherman, et al. (1994). Strategi Belajar Mengajar Matematika, Universitas Terbuka, Departemen Pendidikan dan Kebudayan, Jakarta.

Suherman, et al. (2001). Strategi Pembelajaran Matematika Kontemporer. JICA FPMIPA UPI.

Suherman dkk. (2003). Evaluasi Pembelajaran Matematika. JICA: FPMIPA UPI.

Suherman, E. (2008). Hands-Out Perkuliahan Belajar dan Pembelajaran Matematika-Kompetensi Matematika. Tidak diterbitkan. 